\title{
PENINGKATAN HASIL BELAJAR SISWA MELALUI BLENDED LEARNING PADA MATERI TRIGONOMETRI DI KELAS X FARMASI 1 SMK NEGERI 1 MARTAPURA TAHUN PELAJARAN 2016-2017
}

\author{
Ahmad Sairoji, Dina Huriaty, Mayang Gadih Ranti \\ Program Studi Pendidikan Matematika STKIP PGRI Banjarmasin \\ e-mail: ahmadsairoji20@gmail.com, dina_rty@yahoo.co.id, mayanggadih@gmail.com
}

\begin{abstract}
Abstrak: Tujuan penelitian ini adalah mendeskripsikan aktivitas siswa dalam model pembelajaran koperatif tipe jigsaw dan mengetahui peningkatan hasil belajar siswa melalui blended learning pada materi trigonometri di kelas X Farmasi 1 SMK Negeri 1 Martapura tahun pelajaran 2016-2017. Metode penelitian yang digunakan dalam penelitian ini adalah Penelitian Tindakan Kelas (PTK). Subjek penelitian adalah siswa kelas X Farmasi 1 SMK Negeri 1 Martapura tahun pelajaran 20162017, yang berjumlah 37 siswa yang terdiri atas 8 siswa laki-laki dan 29 siswa perempuan, sedangkan objek penelitian adalah aktivitas dan hasil belajar. Teknik pengumpulan data menggunakan teknik dokumentasi, observasi, dan tes. Teknik analisis data yang digunakan adalah persentase, rata-rata, dan modus. Hasil Penelitian menunjukkan bahwa aktivitas siswa berada pada kualifikasi sangat tinggi dan hasil belajar siswa mengalami peningkatan dari siklus I ke siklus II dari kualifikasi baik menjadi sangat baik.
\end{abstract}

Kata Kunci: blended learning, hasil belajar, trigonometri

Pendidikan merupakan pengalaman belajar yang berlangsung secara bertahap. Pendidikan memegang peranan penting dalam mempersiapkan sumber daya manusia yang berkualitas. Upaya untuk meningkatkan mutu pendidikan perlu dilakukan secara menyeluruh dan dilakukan di setiap jenjang pendidikan. Usman (1995, hal. 4) mengemukakan bahwa proses belajar mengajar merupakan suatu proses yang mengandung serangkaian perbuatan guru dan siswa atas dasar hubungan timbal balik yang berlangsung dalam situasi edukatif untuk mencapai tujuan tertentu. Interaksi atau hubungan timbal balik antara guru dan siswa itu merupakan syarat utama bagi berlangsungnya proses belajar mengajar. Interaksi yang terjadi pada saat proses belajar mengajar adalah interaksi edukatif. Dalam hal ini interaksi terjadi bukan hanya sekedar untuk menyampaikan materi pelajaran, melainkan penanaman sikap dan nilai pada diri siswa yang sedang belajar.

Saat ini pendidikan di Indonesia menggunakan Kurikulum 2013. Guru dan siswa harus dapat menggunakan teknologi, baik itu perangkat hardware maupun software, dan menggunakan jaringan offline maupun online. Dampak dari tuntutan tersebut menjadikan semakin banyak orang mengembangkan teknologi untuk pendidikan salah satunya yaitu dengan pembelajaran elektronik atau yang biasa disebut dengan $e$ learning baik secara online maupun secara offline. Model pembelajaran yang menggunakan e-learning secara online maupun secara offline disebut Blended Learning . 
Blended learnig merupakan istilah yang berasal dari bahasa Inggris, yang terdiri dari dua suku kata, blended dan learning. Blended artinya campuran atau kombinasi yang baik. Blended learning ini pada dasarnya merupakan gabungan keunggulan pembelajaran yang dilakukan secara tatap muka dan secara virtual (Husamah, 2014, hal. 11). Ada tiga komponen dalam blended learning, yaitu (1) Face-to-Face atau Pembelajaran tatap muka, (2) E- Learnig Offline dan Online dan (3) Mobile Learning.

Face-to-Face atau Pembelajaran tatap muka adalah kegiatan pembelajaran berupa proses interaksi langsung antara peserta didik dan pendidik yang mampu mendukung keterlaksanaan blended learning. pembelajaran tatap muka ini dimaksudkan untuk memberikan rambu-rambu dalam pelaksanaan pembelajaran, serta mendekatkan hubungan emosional antara peserta didik dan pengajar. Aplikasi e-learning offline adalah pengembangan media pembelajaran berbasis komputer yang tidak menggunakan jaringan internet. Sistem ini menggunakan komputer sebagai alat bantu belajar. Sementara itu, $e$ learning online merupakan kegiatan pembelajaran yang memanfaatkan jaringan internet, LAN, WAN sebagai metode penyampaian interaksi, dan fasilitasi serta mendukung berbagai bentuk layanan belajar lainnya. Mobile-learning adalah suatu pembelajaran yang mengacu pada pemanfaatan teknologi informasi dan komunikasi sebagai media pembelajaran sehingga pembelajar dapat mengakses materi, arahan dan aplikasi yang berkaitan dengan pelajaran tanpa dibatasi oleh ruang dan waktu, di mana pun dan kapan pun.

Soekartawi dalam Husamah (2014, hal. 27), menyarankan enam tahapan dalam merancang dan menyelenggarakan blended learning agar hasilnya optimal. Keenam tahapan tersebut adalah (1) menetapkan macam dan materi bahan ajar, kemudian mengubah atau menyiapkan bahan ajar tersebut menjadi bahan ajar yang memenuhi syarat pembelajaran jarak jauh, menetapkan rancangan blended learning yang digunakan, (3) mentapkan format pembelajaran online, apakah bahan ajar tersedia dalam format HTML, PDF, atau yang lainnya, (4) melakukan uji coba terhadap rancangan yang dibuat, (5) menyelenggarakan blended learning dengan baik sambil menugaskan instruktur khusus yang tugas utamanya menjawab pertanyaan peserta didik, dan (6) menyiapkan kriteria untuk melakuakan evaluasi pelaksanaan blended learning.

Blended learning yang diterapkan dalam pembelajaran akan semakin mendorong siswa menjadi lebih aktif apabila dipadukan dengan menggunakan model pembelajaran tertentu. Pembelajaran yang dapat membuat siswa aktif dan pembelajaran menjadi efektif dapat dilakukan dengan menggunakan model-model pembelajaran kooperatif (Priansa, 2015, hal. 243). Pembelajaran kooperatif merupakan model pembelajaran yang menyajikan ide bahwa peserta didik harus mampu melaksanakan kerja sama antara yang satu dengan yang lainnya melalui sebuah tim dalam proses pembelajaran yang lebih bertanggung jawab. Salah satu tipe model pembelajaran kooperatif adalah model kooperatif tipe Jigsaw.

Menurut Lie dalam Rusman (2014, hal. 219), bahwa pembelajaran kooperatif model jigsaw merupakan model belajar koperatif dengan cara siswa belajar dalam kelompok kecil yang terdiri dari empat sampai enam orang secara heterogen dan 
siswa bekerja sama saling ketergantungan positif dan bertanggungjawab secara mandiri.

Hasil belajar siswa X Farmasi 1 SMK

Negeri 1 Martapura pada materi trigonometri masih rendah dan terlihat dari hasil ulangan harian siswa hanya 55\% siswa yang berhasil mencapai batas Kriteria Ketuntasan Minimal (KKM) yang diterapkan di sekolah ini untuk individualnya $\geq 75$. Dengan demikian guru harus mengadakan remedial agar dapat memperbaiki nilai siswa. Hal ini mengidentifikasikan bahwa pembelajaran pada pokok bahasan trigonometri dengan metode yang diterapkan oleh guru selama ini perlu diperbaiki.

Beberapa penelitian terdahulu menunjukkan bahwa implementasi blended learning dapat meningkatkan aktivitas, sikap kemandirian belajar, dan hasil belajar peserta didik dalam pembelajaran biologi. Peningkatan peserta didik dapat dilihat melalui hasil angket dan observasi. Rata-rata nilai ulangan harian peserta didik pada prasiklus sebesar 55,33\%, siklus I sebesar $67,33 \%$, dan siklus II sebesar $75,67 \%$. Kedua penelitian ini menunjukkan bahwa blended learning dapat meningkatkan hasil belajar siswa (Husamah, 2014, hal. 34).

Hasil penelitian yang dilakukan oleh Nobella (2015) menyatakan bahwa pembelajaran blended learning dapat meningkatkan hasil belajar siswa pada pembelajaran matematika. Hasil belajar siswa menunjukkan sangat baik, pada siklus I terdapat 29 siswa yang berhasil dari 38 siswa, dan pada siklus II terdapat 35 siswa yang berhasil dari 38 siswa.

Penelitian ini bertujuan untuk: (1) mendeskripsikan aktivitas siswa dalam model pembelajaran koperatif tipe jigsaw dan (2) mengetahui peningkatan hasil belajar siswa melalui blended learning pada materi trigonometri di kelas X Farmasi 1 SMK Negeri 1 Martapura tahun pelajaran 20162017.

Berdasarkan uraian di atas, maka hipotesis tindakan dalam penelitian ini adalah "Jika pembelajaran matematika dengan menggunakan blended learning dilakukan dengan tepat dan benar maka akan meningkatkan hasil belajar siswa pada materi trigonometri di kelas X Farmasi 1 SMK Negeri 1 Martapura"

\section{Metode Penelitian}

Metode penelitian ini adalah metode penelitian tindakan kelas (PTK) yang dilaksanakan melalui 4 (empat) tahap yaitu
(1) perencanaan,
(2) pelaksanaan, pengamatan, (4) refleksi.

Subjek penelitian ini adalah siswa kelas X Farmasi 1 SMK Negeri 1 Martapura tahun pelajaran 2016-2017 yang berjumlah 37 siswa yang terdiri dari 8 siswa laki-laki dan 29 siswa perempuan. Objek penelitian adalah aktivitas dan hasil belajar siswa kelas $\mathrm{X}$ Farmasi 1 SMK Negeri 1 Martapura tahun pelajaran 2016-2017 dalam kegiatan pembelajaran dengan model lended learning pada materi trigonometri.

Penelitian ini dilaksanakan di SMK Negeri 1 Martapura yang beralamatkan di jalan pendidikan No. 79, Rt. 03, Rw. 03, Kelurahan Sekumpul, Martapura. pada bulan Februari-Juni 2017.

Pengumpulan data dari aktivitas dan hasil belajar siswa dalam penelitian ini menggunakan teknik dokumentasi, observasi, dan tes. Data dianalisis menggunakan teknik persentase, rata-rata dan modus, yang diuraikan berikut ini.

\section{a. Analisis Data Aktivitas Siswa}


Aktivitas siswa dihitung dengan menggunakan teknik analisis persentase dari Sudijono (2009: 43).

$$
P=\frac{f}{n} x 100 \%
$$

Keterangan:

$\mathrm{P}=$ Persentase siswa yang tuntas

$\mathrm{f}=$ Jumlah siswa yang tuntas

$\mathrm{n}=$ Jumlah seluruh siswa

Tabel 1. Kriteria Interprestasi Skor

\begin{tabular}{|c|c|}
\hline Interpretasi & Kualifikasi \\
\hline $0 \% \leq \mathrm{P} \leq 20 \%$ & Sangat rendah \\
\hline $20 \%<\mathrm{P} \leq 40 \%$ & Rendah \\
\hline $40 \%<\mathrm{P} \leq 60 \%$ & Sedang \\
\hline $60 \%<\mathrm{P} \leq 80 \%$ & Tinggi \\
\hline $80 \%<\mathrm{P} \leq 100 \%$ & Sangat Tinggi \\
\hline
\end{tabular}

\section{b. Analisis Data Hasil Belajar Siswa}

Nilai hasil belajar siswa diinterprestasikan dengan menggunakan standar yang telah ditetapkan oleh pihak sekolah berdasarkan Kriteria Ketuntasan Minimal (KKM), yaitu secara individual siswa dinyatakan tuntas dalam pembelajarannya jika memperoleh nilai $\geq 75$ dan secara klasikal suatu kelas dinyatakan lulus dalam belajarnya jika $80 \%$ dari jumlah siswa memperoleh nilai $\geq 75$.

\section{Indikator Keberhasilan}

Indikator keberhasilan penelitian ini adalah penelitian dapat dikatakan berhasil jika secara klasikal kelas dinyatakan tuntas dalam belajarnya $\geq 80 \%$ dari jumlah siswa memperoleh nilai $\geq 75$ dan hasil belajar siswa meningkat dari siklus sebelumnya yaitu dari siklus I dan siklus II dan minimal berada dalam kualifikasi "baik".

\section{Hasil Penelitian dan Pembahasan}

\section{Hasil}

Hasil selama pelaksanaan pembelajaran dirangkum persiklus.

\section{a. Siklus I}

Pembelajaran pada siklus I berjalan sesuai rencana yaitu dua kali pertemuan dan satu kali evaluasi. Pembelajaran dilakukan secara offline dan online dengan menggunakan sofware edmudo. Pada kegiatan pembelajaran guru membentuk kelompok siswa (organisasi belajar) secara heterogen dilihat dari nilai rapot pada pelajaran matematika semester yang terdiri atas 8 kelompok, setiap kelompok terdiri atas 3-5 orang siswa. Siswa bekerja secara berkelompok mengerjakan LKK yang diunduh melalui situs edmudo.

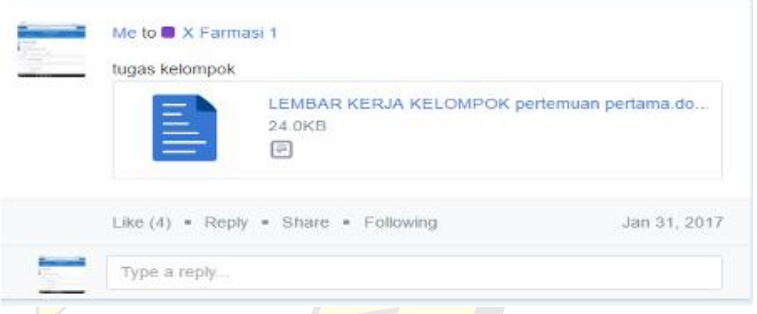

Gambar 1. LKK Pertemuan I Siklus I pada Situs Edmudo

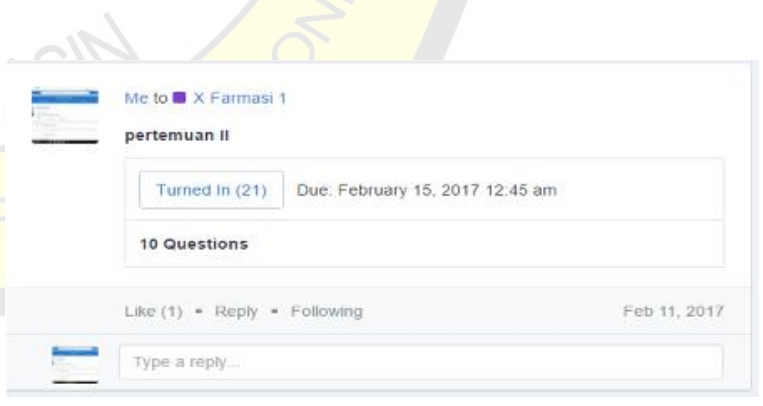

Gambar 2. LKK Pertemuan 2 Siklus I pada Situs Edmudo

Materi pada pertemuan I adalah Perbandingan Trigonometri Sudut Siku-Siku dan pada pertemuan II adalah Perbandingan trigonometri sudut Istimewa. Pada dua kali 
pertemuan, pembelajaran menggunakan model koperatif tipe jigsaw berjalan sesuai dengan langkah. Ada sedikit modifikasi pada langkah pembelajarannya, yaitu pada langkah kedua yaitu kelompok ahli dibagi berdasarkan nomor soal. Aktivitas siswa dalam pembelajaran siklus I masih kurang aktif dalam mempresentasikan hasil diskusi kelompoknya, bertanya mengenai hal yang dianggap penting dalam pembelajaran serta memberikan pendapat dan kesimpulan terhadap materi yang telah dipelajari. Hasil observasi dapat dilihat pada tabel berikut.

Tabel 2. Persentase Aktivitas Siswa pada Siklus I

\begin{tabular}{|c|c|c|}
\hline Aspek yang Diamati & $\begin{array}{c}\text { Persen } \\
(\%)\end{array}$ & $\begin{array}{c}\text { Kualifi } \\
\text { kasi }\end{array}$ \\
\hline $\begin{array}{l}\text { Siswa memperhatikan } \\
\text { penjelasan guru tentang } \\
\text { langkah-langkah pembelajaran }\end{array}$ & 94,59 & $\begin{array}{l}\text { Sangat } \\
\text { tinggi }\end{array}$ \\
\hline $\begin{array}{l}\text { Siswa mendengar dan } \\
\text { menyimak terhadap materi } \\
\text { yang disampaikan guru }\end{array}$ & 83,78 & $\begin{array}{l}\text { Sangat } \\
\text { tinggi }\end{array}$ \\
\hline $\begin{array}{l}\text { Siswa membentuk kelompok } \\
\text { sesuai dengan arahan guru }\end{array}$ & 100 & $\begin{array}{l}\text { Sangat } \\
\text { tinggi }\end{array}$ \\
\hline $\begin{array}{l}\text { Siswa mengerjakan tugas dan } \\
\text { berdiskusi dalam kelompok }\end{array}$ & 58,11 & Sedang \\
\hline $\begin{array}{l}\text { Siswa membentuk kelompok } \\
\text { baru sesuai dengan arahan } \\
\text { guru }\end{array}$ & 100 & $\begin{array}{l}\text { Sangat } \\
\text { tinggi }\end{array}$ \\
\hline $\begin{array}{l}\text { Siswa berdiskusi dengan } \\
\text { kelompok baru }\end{array}$ & 41,89 & Sedang \\
\hline $\begin{array}{l}\text { Siswa kembali ke kelompok } \\
\text { awal }\end{array}$ & 100 & $\begin{array}{l}\text { Sangat } \\
\text { tinggi }\end{array}$ \\
\hline $\begin{array}{l}\text { Siswa mempresentasikan hasil } \\
\text { diskusi kelompoknya }\end{array}$ & 22,97 & Rendah \\
\hline $\begin{array}{l}\text { Siswa menyimak dan } \\
\text { menanyakan hal-hal yang } \\
\text { dianggap perlu mengenai } \\
\text { materi yang telah dipelajari }\end{array}$ & 41,89 & Sedang \\
\hline $\begin{array}{l}\text { Siswa memberikan pendapat } \\
\text { tentang kesimpulan hasil } \\
\text { pembelajaran }\end{array}$ & 22,97 & Rendah \\
\hline $\begin{array}{l}\text { Siswa menyimak informasi } \\
\text { terakhir dari guru }\end{array}$ & 83,78 & $\begin{array}{l}\text { Sangat } \\
\text { tinggi }\end{array}$ \\
\hline
\end{tabular}
belajar siswa secara klasikal 78,38\%, karena siswa yang memenuhi KKM yaitu $\geq 75,00$ sebanyak 29 siswa dan 8 siswa yang memperoleh nilai $<75,00$. Nilai rata-rata 73,38 dari 37 siswa dengan kualifikasi baik.

Secara klasikal ketuntasan belajar pada siklus I telah mencapai $78 \%$. Hal ini menunjukkan bahwa hasil belajar siswa kelas $\mathrm{X}$ Farmasi 1 pada siklus I belum memenuhi indikator keberhasilan penelitian yang telah ditetapkan, sehingga harus dilanjutkan pada siklus selanjutnya.

Berdasarkan hasil observasi dan evaluasi selama pelaksanaan siklus I ada beberapa hal penting yang perlu diperhatikan dan diperbaiki untuk perencanaan tindakan pada siklus selanjutnya. Kegiatan pembelajaran melalui blended learning dengan menggunakan model pembelajaran koperatif tipe jigsaw untuk meningkatkan hasil belajar siswa pada siklus I belum sepenuhnya berjalan dengan baik. Terlihat dari beberapa nilai siswa yang belum memenuhi KKM dikarenakan kurang terbiasanya menggunakan fitur situs edmodo. Dan kurang aktifnya siswa dalam mempresentasikan hasil diskusi kelompoknya, bertanya mengenai hal yang dianggap penting dalam pembelajaran serta memberikan pendapat dan kesimpulan terhadap materi yang telah dipelajari.

Untuk mengatasi permasalahanpermasalahan pada siklus I, maka peneliti merekomendasikan beberapa perbaikan di suklus II yaitu, pengawasan guru yang menyeluruh pada semua siswa terutama pada siswa yang pemahamannya lamban dengan harapan semua siswa dapat terlibat aktif dalam proses pembelajaran dan pengelolaan waktu pembelajaran diusahakan seefektif mungkin dan sesuai dengan rencana yang 
telah dibuat. Bagi siswa yang bermasalah dengan akses pada situs edmudo diberikan keringanan dengan menjawab LKS secara manual.

\section{b. Siklus II}

Pembelajaran pada siklus II dengan materi lanjutan dari siklus I yaitu Perbandingan Trigonometri pada Sudut Berelasi berjalan menggunakan model koperatif tipe jigsaw yang telah di-modifikasi sesuai dengan hasil refleksi pada siklus I. Pembelajaran tetap dilakukan secara offline dan online menggunakan software edmudo.

Hasil observasi aktivitas siswa pada siklus II berhasil meningkatkan aktivitas siswa dalam bertanya dan mengemukakan pendapat serta menyimpulkan hasil pembelajaran juga sudah meningkat.

Pengelolaan pembelajaran yang dilakukan oleh guru secara keseluruhan berlangsung dengan lancar, guru sudah mampu melaksanakan semua rencana tindakan yang telah dibuat. Pemberian motivasi, bimbingan terhadap siswa secara menyeluruh, pengelolaan waktu dalam pembelajaran serta perhatian guru kepada siswa sudah meningkat. Persentase aktivitas siswa dalam setiap pertemuan dapat dilihat pada tabel 4 .
Tabel 3

Persentase Aktivitas Siswa pada Siklus II

\begin{tabular}{|c|c|c|}
\hline Aspek yang Diamati & $\begin{array}{l}\text { PPerse } \\
\mathrm{n}(\%)\end{array}$ & $\begin{array}{l}\text { Kualifik } \\
\text { asi }\end{array}$ \\
\hline $\begin{array}{l}\text { Siswa memperhatikan penjelasan } \\
\text { guru tentang langkah-langkah } \\
\text { pembelajaran }\end{array}$ & 98,65 & $\begin{array}{l}\text { Sangat } \\
\text { tinggi }\end{array}$ \\
\hline $\begin{array}{l}\text { Siswa mendengar dan menyimak } \\
\text { terhadap materi yang } \\
\text { disampaikan guru }\end{array}$ & 98,19 & $\begin{array}{l}\text { Sangat } \\
\text { tinggi }\end{array}$ \\
\hline $\begin{array}{l}\text { Siswa membentuk kelompok } \\
\text { sesuai dengan arahan guru }\end{array}$ & 100 & $\begin{array}{l}\text { Sangat } \\
\text { tinggi }\end{array}$ \\
\hline $\begin{array}{l}\text { Siswa mengerjakan tugas dan } \\
\text { berdiskusi dalam kelompok }\end{array}$ & 72,97 & Tinggi \\
\hline $\begin{array}{l}\text { Siswa membentuk kelompok } \\
\text { baru sesuai dengan arahan guru }\end{array}$ & 98,65 & $\begin{array}{l}\text { Sangat } \\
\text { tinggi }\end{array}$ \\
\hline $\begin{array}{l}\text { Siswa berdiskusi dengan } \\
\text { kelompok baru }\end{array}$ & 66,22 & Tinggi \\
\hline Siswa kembali ke kelompok awal & 100 & $\begin{array}{l}\text { Sangat } \\
\text { tinggi }\end{array}$ \\
\hline $\begin{array}{l}\text { Siswa mempresentasikan hasil } \\
\text { diskusi kelompoknya }\end{array}$ & 48,65 & Sedang \\
\hline $\begin{array}{l}\text { Siswa menyimak dan } \\
\text { menanyakan hal-hal yang } \\
\text { dianggap perlu mengenai materi } \\
\text { yang telah dipelajari }\end{array}$ & 54,05 & Sedang \\
\hline $\begin{array}{l}\text { Siswa memberikan pendapat } \\
\text { tentang kesimpulan hasil } \\
\text { pembelajaran }\end{array}$ & 50,00 & Sedang \\
\hline $\begin{array}{l}\text { Siswa menyimak informasi } \\
\text { terakhir dari guru }\end{array}$ & 75,68 & Tinggi \\
\hline
\end{tabular}

Berdasarkan Tabel 4 di atas, saat siswa memperhatikan penjelasan guru tentang langkah-langkah pembelajaran, mendengarkan dan menyimak terhadap materi yang disampaikan, membentuk kelompok asal dan kelompok ahli, serta kembali ke kelompok asal aktivitas siswa pada siklus I dan II berkualifikasi sangat tinggi karena mereka antusias dalam melaksanakan pembelajaran. Pada saat siswa mengerjakan dan berdiskusi kelompok pada siklus I 
aktivitas siswa berada pada kualifikasi sedang, setelah diadakan siklus II aktivitas siswa terlihat ada peningkatan dari kualifikasi sedang menjadi kualifikasi tinggi karena siswa tampak bersemangat dan lebih serius dalam berdiskusi. Pada saat siswa mempresentasikan hasil diskusi kelompok dan memberikan pendapat tentang kesimpulan hasil pembelajaranpada siklus I aktivitas siswa berada pada kualitas rendah dan pada siklus II meningkat berada pada kualifikasi sedang. Saat siswa menyimak dan menanyakan hal-hal yang dianggap perlu mengenai materi yang telah dipelajari pada siklus I dan siklus II tidak ada peningkatan yaitu tetap berkualifikasi sedang. Saat siswa menyimak informasi terakhir dari guru pada siklus I berkualitas sangat tinggi namun pada siklus II ada penurunan menjadi tinggi hal ini dikarenakan siswa ingin mempersiapkan materi produktif yang akan berlangsung setelah kegiatan pembelajaran matematika.

Berdasarkan hasil pada siklus I dan II dapat disimpulkan bahwa pada siklus I siswa berada pada kualifikasi tinggi, sedangkan pada siklus II aktivitas siswa berada pada kualifikasi sangat tinggi. Untuk deskripsi aktivitas siswa pada siklus I dan II secara ringkas dapat dilihat pada gambar 3 berikut.

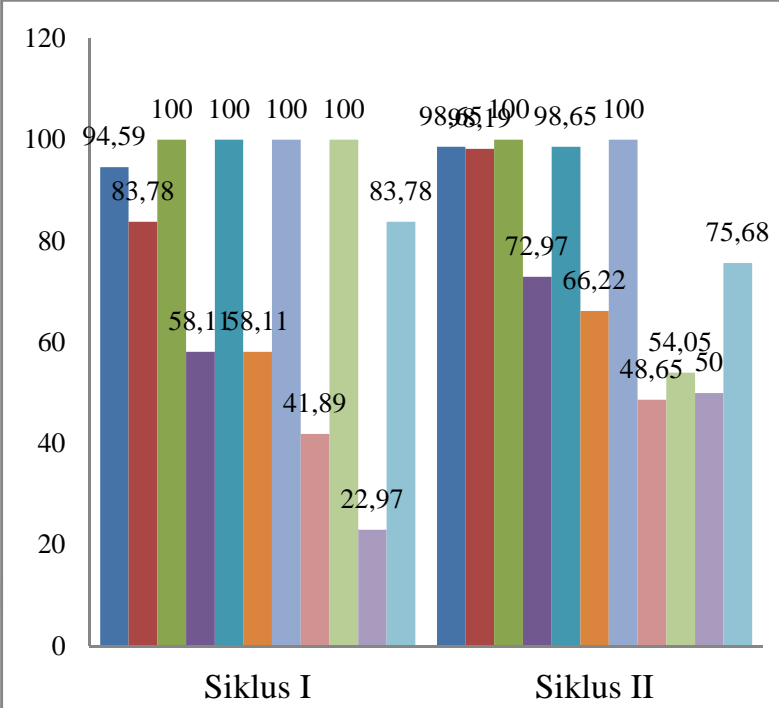

- Siswa memperhatikan penjelasan guru tentang langkah-langkah pembelajaran

- Siswa mendengar dan menyimak terhadap materi yang disampaikan guru

- Siswa membentuk kelompok sesuai dengan arahan guru

- Siswa mengerjakan tugas dan berdiskusi dalam kelompok

- Siswa membentuk kelompok baru sesuai dengan arahan guru

- Siswa berdiskusi dengan kelompok baru

- Siswa kembali ke kelompok awal

- Siswa mempresentasikan hasil diskusi kelompoknya

Siswa menyimak dan menanyakan hal-hal yang dianggap perlu mengenai materi yang telah dipelajari

- Siswa memberikan pendapat tentang kesimpulan hasil pembelajaran

- Siswa menyimak informasi terakhir dari guru

\section{Gambar 3. Persentase Aktivitas Siswa pada Siklus I dan II}

Hasil belajar siswa meningkat dimana pada evaluasi akhir siklus I diperoleh nilai rata-rata adalah 78,38 dari 37 siswa. Pada evaluasi akhir siklus II diperoleh nilai ratarata 83,78 dari 37 siswa. Nilai rata-rata hasil belajar siswa dapat dilihat pada grafik berikut. 


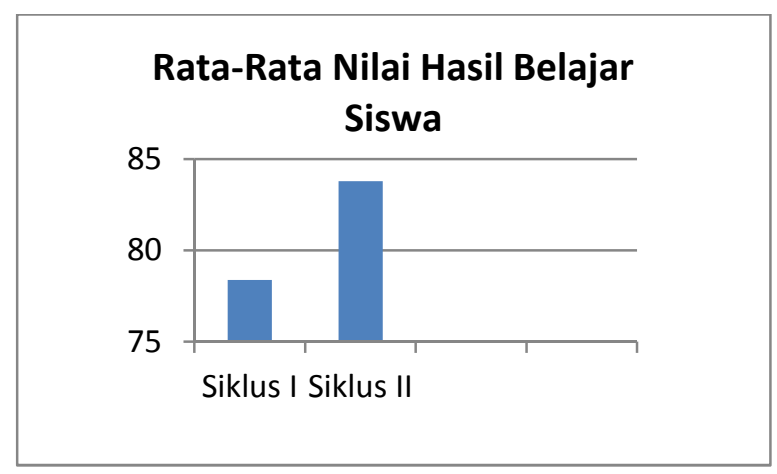

Gambar 4. Rata-Rata Nilai Hasil Belajar Siswa

Ketuntasan belajar siswa secara klasikal siklus II mencapai $83,78 \%$ atau hanya 6 dari 37 siswa yang mendapat nilai yang belum mencapai 75,00 . Nilai rata-rata 82,16 dari 35 siswa dan tergolong dalam kualifikasi baik.

Secara klasikal hasil belajar siswa telah mencapai $80 \%$. Hal ini menunjukkan bahwa hasil belajar siswa kelas X Farmasi 1 pada siklus II memenuhi indikator keberhasilan penelitian yang telah ditetapkan.

\section{Pembahasan}

Berdasarkan hasil penelitian diakhir siklus diperoleh aktivitas siswa dalam model pembelajaran koperatif jigsaw pada materi trigonometri di kelas X Farmasi 1 SMK Negeri 1 Martapura berada pada kualifikasi sangat tinggi. Pada saat siswa mengerjakan dan berdiskusi kelompok pada siklus I aktivitas siswa berada pada kualifikasi sedang, setelah diadakan siklus II aktivitas siswa terlihat ada peningkatan dari kualifikasi sedang menjadi kualifikasi tinggi karena siswa tampak bersemangat dan lebih serius dalam berdiskusi. Pada saat siswa mempresentasikan hasil diskusi kelompok dan memberikan pendapat tentang kesimpulan hasil pembelajaran pada siklus I, aktivitas siswa berada pada kualitas rendah dan pada siklus II meningkat berada pada kualifikasi sedang. Saat siswa menyimak dan menanyakan hal-hal yang dianggap perlu mengenai materi yang telah dipelajari pada siklus I dan siklus II tidak ada peningkatan yaitu tetap berkualifikasi sedang. Saat siswa menyimak informasi terakhir dari guru pada siklus I berkualitas sangat tinggi namun pada siklus II ada penurunan menjadi tinggi hal ini dikarenakan siswa ingin mempersiapkan materi produktif yang akan berlangsung setelah kegiatan pembelajaran matematika.

Aktivitas siswa yang tinggi pada pembelajaran blended learning antara lain disebabkan adanya penggunaan media pembelajaran secara online dengan software edmudo yang membuat pembelajaran lebih menarik dan mendorong siswa untuk terlibat lebih aktif. Hal ini sesuai dengan pendapat Husamah (2014, hal. 35-36) bahwa peserta didik leluasa untuk mempelajari materi pelajaran secara mandiri dengan memanfaatkan materi-materi yang tersedia secara online. Semler dalam Husamah (2014, hal. 11) menegaskan bahwa blended learning mengombinasikan aspek terbaik dari pembelajaran online, aktivitas tatap muka terstruktur, dan praktik dunia nyata, sistem pembelajaran online, latihan di kelas, dan pengamanan berharga bagi diri mereka. Blended learning menggunakan pendekatan yang memberdayakan berbagai sumber informasi yang lain.

Selain itu penggunaan Model Pembelajaran Kooperatif tipe JIGSAW juga mendukung penerapan pembelajaran blended learning. Menurut Lie dalam Rusman (2014, hal. 219) pembelajaran koperatif model jigsaw merupakan model belajar koperatif dengan cara siswa belajar dalam kelompok kecil yang terdiri dari empat sampai enam orang secara heterogen dan siswa bekerja sama saling ketergantungan positif dan bertanggung jawab secara mandiri. 
Hasil belajar siswa juga mengalami peningkatan dari siklus I ke siklus II dari kualifikasi baik menjadi sangat baik. Menurut Bloom dalam Suprijono (2015, hal. 6) hasil belajar mencakup kemampuan kognitif, afektif, dan psikomotorik. Hasil belajar adalah perubahan perilaku secara keseluruhan bukan hanya salah satu aspek potensi kemanusiaan saja. Dengan menggunakan model pembelajaran blended learning dapat meningkatkan kemampuan kognitf, afektif, dan psikomotorik siswa karena siswa terlibat aktif dalam pembelajaran baik secara online maupun offline.

Berdasarkan hasil penelitian dan pembahasan tersebut maka hipotesis tindakan yang dirumuskan dalam penelitian ini, yaitu jika pembelajaran matematika dengan menggunakan blended learning dilakukan dengan tepat dan benar maka akan meningkatkan hasil belajar siswa pada materi trigonometri di kelas X Farmasi 1 SMK Negeri 1 Martapura dapat diterima.

\section{Kesimpulan}

Berdasarkan hasil penelitian yang dilakukan diperoleh aktivita siswa dalam model pembelajaran koperatif jigsaw pada materi trigonometri di kelas X Farmasi 1 SMK Negeri 1 Martapura berada pada kualifikasi sangat tinggi dan hasil belajar siswa kelas X Farmasi 1 SMK Negeri 1 Martapura tahun pelajaran 2016-2017 melalui blended learning menggunakan model pembelajaran koperatif tipe jigsaw pada materi trigonometri mengalami peningkatan dari siklus I ke siklus II dari kualifikasi baik menjadi sangat baik.

\section{Daftar Pustaka}

Amri, Sofan. 2013. Pengembangan dan Model Pembelajaran dalam Kurikulum 2013. Jakarta: Prestasi Pustaka Publisher.

Dimyati dan Mudjiono. 2010. Belajar dan Pembelajaran. Jakarta: PT. Rineka Cipta.

Departemen Pendidikan Nasional. 2008. Panduan Pengembangan Bahan Ajar. Jakarta: Departemen Pendidikan Nasional.

Departemen Pendidikan Nasional. 2014. Kamus Besar Bahasa Indonesia Edisi Keempat. Jakarta: PT Gramedia Pustaka Utama.

Hamalik, Oemar. 2014. Kurikulum dan Pembelajaran. Jakarta: PT Bumi Aksara.

Husamah. 2014. Pembelajaran Bauran (Blended Learning). Jakarta: Prestasi Pustaka Publisher.

Iskandar, Agung. 2012. Panduan Penelitian Tindakan Kelas Bagi Guru. Jakarta: Bentari Buana Murni.

Kesuma, Ameliasari, T. 2013. Menyusun PTK itu Gampang. Jakarta: Erlangga.

Rusman. 2014. Model-Model Pembelajaran Mengembangkan Profesionalisme Guru. Jakarta: PT. Raja Grapindo Persada. 
Sanjaya, Wina. 2006. Kurikulum dan Pembelajaran. Kota: Kencana Predana Media Grup.

Suprijono, Agus. 2013. Cooperative Learning. Yogyakarta: Pustaka Pelajar.

Syah, Muhibbin. 2013. Psikologi Belajar. Jakarta: PT. Raja Grapindo Persada.

Priansa, Donni Juni. 2015. Manajemen Peserta Didik dan Model Pembelajaran. Bandung: Alfabeta.

Usman, Moh. Uzer. 1995. Menjadi Guru Profesional. Bandung: Rosda Karya. 